DOI: 10.15587/2312-8372.2019.180224

\section{Bilyk 0., \\ Kochubei-Lytrynenko O., Bondarenko Y., Chernyushok 0.}

\title{
THE USE OF AN ENZYME PREPARATION WHEN USING CALCIUM ACETATE IN WHEAT BREAD TECHNOLOGY
}

Важливою проблемою хлібопечення є запобігання основних причин псування хліба, а саме розвиток мікроорганізмів, які за сприятливих для них умов активізуються й призводять до повної непридатності продукту до споживання. Спори бактерій групи картопляної палички досить стійкі до термічного впливу, вони залишаються життєздатними навіть за температур, близьких до $130{ }^{\circ}$ С, але чутливі до кислого середовища. Використання ацетату кальцію в рецептурі пшеничного хліба здійснюватиме пригнічуюючий вплив на мікроорганізми, що буде впливати і на якість виробів. Для покращання якості таких виробів доцільно використовувати ферменти амілолітичної дї для інтенсифікацї̈ бродіння тіста та добавки окисної дї̈ для зменшення його липкості і розпливання. Об'єктом досліджень у роботі було тісто з пшеничного борошна першого сорту, в рецептуру якого включено ащетат кальцію, ферментний препарат Alphaтаlt $V$ та аскорбінова кислота.

Встановлено, що з точки зору впливу на якість готових виробів раціональним дозуванням ацетату кальцію є 0,3\% до маси борошна. Оптимальним дозуванням ферментного препарату Alphamalt Vє 0,015\% до маси борошна та аскорбінової кислоти - 0,006 \%. Доведено, що внесення даної композиції харчових добавок покращує газоутворювальну здатність на 15..20\% порівняно з контролем та виробами, що містить тільки ацетат кальцію. Встановлено позитивний вплив використання ферментного препарату амілолітичної дї поряд з ацетатом кальцію на підйомну силу дріжджів. Це сприяє інтенсифікації бродіння тіста та збільшенню питомого об'єму і пористості пшеничного хліба. Встановлено, що використання композицї харчових добавок позитивно впливає на пружньо-еластичні властивості тіста: зменшується розпливання кульки тіста та збільшується газоутримуюча здатність на 10...13\% порівняно з виробами з ацетатом кальцію. Це зумовлює збільшення питомого об’єму та формостійкості хліба.

Завдяки розробленій композичї харчових добавок забезпечується можливість використання ацетату кальцію для інгібування картопляної палички, не втрачаючи якість готових виробів.

Ключові слова: пшеничний хліб, картопляна хвороба, ацетат кальцію, ферментний препарат Alphamalt $V$, аскорбінова кислота, питомий об'єм.

\section{Introduction}

From the practice of baking, it is known that bread is made from flour with reduced baking properties, is at greater risk of contracting a potato disease than bread from flour of normal quality. To combat potato disease, along with biological methods [1], various additives of a chemical nature that have passed a hygienic test are used [2]. These dietary supplements include:

acetic acid in an amount of $0.1 \ldots 0.2 \%$ (in terms

of $100 \%$ acetic acid) to the mass of flour [3];

- lactic acid in an amount of $0.2 \ldots 0.3 \%$ by weight

of flour [4, 5];

- calcium acetate in an amount of $0.2 \ldots 0.4 \%$ by weight of flour [2,6];

- acetic acid in an amount of $0.1 \%$ together with calcium acetate in an amount of $0.2 \%$ by weight of flour [2, 7]; - propionic acid or propionates of sodium, potassium, calcium in an amount of $0.3 \ldots 0.5 \%$ by weight of flour $[8,9]$.
The introduction of food additives prevents the development of vegetative forms of bacteria of potato bacillus, but the bacteria themselves and their spores are neutralized. When using these additives, the fermentation rate of the dough decreases, its volume decreases by $15 \ldots 20 \%$, the crumb structure, porosity, taste and aroma deteriorate $[1,2]$. The most common in the baking industry to prevent the development of potato bread disease is calcium acetate. To mitigate the action of calcium acetate, namely, intensification of the fermentation process, reducing the stickiness of the dough and its spreading, it is recommended to increase the yeast content, add malt, tea leaves, enzyme preparations of amylolytic action, ascorbic acid [10].

Based on this, it is important to conduct research on the use of an enzyme preparation with an amylolytic effect and ascorbic acid to improve the quality of bakery products under conditions of using calcium acetate as an inhibitor of potato disease. 
The object of research in the work is dough made from premium wheat flour and the quality of wheat bread, the formulation of which includes calcium acetate.

The aim of research is establishment of the effect of the enzyme preparation of amylolytic and ascorbic acid on the quality of wheat bread.

\section{Methods of research}

The studies used calcium acetate (Finnish company LLC Leipurin) - this is a white powder that contains $99.2 \%$ of pure calcium acetate, wt. \% min. The enzyme preparation of the mushroom $\alpha$-amylase Alphamalt $\mathrm{V}$ of the German company Muhlenchemie.

To assess the quality of bread with the addition of calcium acetate and an enzyme preparation, a trial laboratory baking was performed. During the study, dough was prepared from premium flour with the introduction of:

- calcium acetate in an amount of $0.2 ; 0.3 ; 0.4$ and

$0.5 \%$ by weight of flour;

- Alphamalt $\mathrm{V}$ enzyme preparation in an amount of $0.005 ; 0.01 ; 0.015$ and $0.02 \%$ by weight of flour;

- ascorbic acid - 0.002; 0.004; 0.006 and $0.008 \%$ by weight of flour.

The control sample was as follows: first grade wheat flour $-100 \mathrm{~g}$, yeast $-3 \%$, salt $-1.5 \%$. The dough was kneaded in a dough mixing machine Esher (Italy) for 4 minutes at the first speed and 7 minutes at the second. The dough was prepared in an unpaired way with a mass fraction of dough moisture - $44 \%$. During the fermentation period, the dough was kneaded 60 and $120 \mathrm{mi}-$ nutes after mixing. Dough processing was carried out manually, proofing of dough pieces was carried out in an open cabinet at a temperature of $38 \pm 2{ }^{\circ} \mathrm{C}$ and a relative humidity of $78 \pm 2 \%$ until ready. Products were baked in a cupboard oven at a temperature of $220-240{ }^{\circ} \mathrm{C}$ with humidification of the baking chamber.

The quality of bread was evaluated by physicochemical (specific volume, acidity) and organoleptic characteristics (appearance, surface condition of the crust, structure of porosity, taste, smell) [11]. A comprehensive quality indicator was assessed by a score on the quality of bakery products [12]. The gas-retaining ability of the dough was determined by the change in the specific volume of $100 \mathrm{~g}$ of the dough in the cylinder during the dough fermentation [12]. Elastic-elastic properties of the dough were studied on a pharynograph of «Brabender» company (Germany) [12]. The results of experimental studies were subjected to statistical processing, implemented using standard Microsoft Office software packages.

\section{Research results and discussion}

To determine the optimal dosage of calcium acetate, the enzyme preparation Alphamalt $\mathrm{V}$ and ascorbic acid, laboratory baking was performed and the quality of wheat bread was examined. Based on the data obtained, a comprehensive quality indicator was calculated. The data obtained are given in Table 1.

It is found that, according to a comprehensive quality indicator, the rational dosage of calcium acetate is $0.3 \%$ by weight of flour. The optimal dosage of the enzyme preparation Alphamalt $\mathrm{V}$ is $0.015 \%$ by weight of flour and ascorbic acid $-0.006 \%$ by weight of flour.
Determination of the optimal dosage of food additives by a comprehensive quality indicator, $n=3, p \leq 0.95$

\begin{tabular}{|c|c|c|c|c|c|}
\hline Indicator & $\begin{array}{l}\text { Control without } \\
\text { additives }\end{array}$ & \multicolumn{4}{|c|}{$\begin{array}{l}\text { Dosage (\%) to the mass } \\
\text { of flour }\end{array}$} \\
\hline \multirow{3}{*}{$\begin{array}{l}\text { Comprehensive } \\
\text { quality indicator }\end{array}$} & \multirow{3}{*}{78.4} & \multicolumn{4}{|c|}{ Calcium acetate } \\
\hline & & 0.2 & 0.3 & 0.4 & 0.5 \\
\hline & & 77.8 & 77.2 & 69.1 & 64.5 \\
\hline \multirow{3}{*}{$\begin{array}{l}\text { Comprehensive } \\
\text { quality indicator }\end{array}$} & \multirow{3}{*}{78.4} & \multicolumn{4}{|c|}{ Alphamalt V enzyme preparation } \\
\hline & & 0.005 & 0.010 & 0.015 & 0.020 \\
\hline & & 82.1 & 87.8 & 93.0 & 91.6 \\
\hline \multirow{3}{*}{$\begin{array}{l}\text { Comprehensive } \\
\text { quality indicator }\end{array}$} & \multirow{3}{*}{78.4} & \multicolumn{4}{|c|}{ Ascorbic acid } \\
\hline & & 0.002 & 0.004 & 0.006 & 0.008 \\
\hline & & 81.4 & 87.5 & 88.2 & 86.5 \\
\hline
\end{tabular}

When determining the effect of food additives on microbiological and biochemical processes in the dough with calcium acetate, it was prepared in a random manner. The fermentation rate of the dough by the amount of carbon dioxide released during the fermentation and proofing periods of the dough, as well as the fermentation activity of the yeast by raising the dough are studied.

The research results presented in Fig. 1, 2 indicate that food additives stimulate the fermentative activity of yeast, resulting in increased release of carbon dioxide during fermentation and proofing of the dough. The reason for this is the accumulation of maltose in the dough from the action of the enzyme preparation Alphamalt V.

Since one of the problems in the production of bread from calcium acetate is the deterioration of the structural and mechanical properties of the dough, on which the shape stability of the dough pieces during baking depends, the volume of bread and the structure of the bread crumb, the feasibility of using food additives for these properties is investigated.

The results of studies obtained with the help of a pharynograph (Table 2) indicate that when the enzyme preparation Alphamalt $\mathrm{V}$ and ascorbic acid are added to the dough with calcium acetate, these indicators can be improved to the level in the control. Thus, due to this, the elasticity increased by $3.7 \%$ compared with the control and by $27 \%$ compared with the dough with calcium acetate. This can be explained by the strengthening of the gluten frame of the dough.

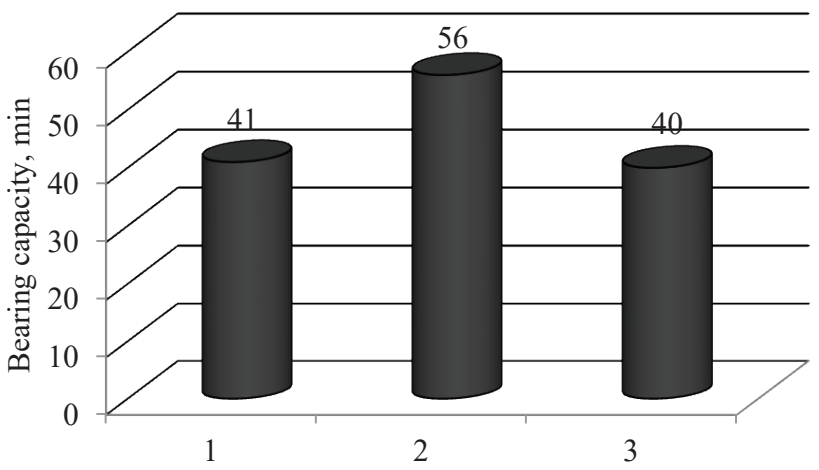

Fig. 1. The effect of food additives on the bearing capacity of yeast: 1 - control (without additives); $2-0.3 \%$ calcium acetate; $3-0.3 \%$ calcium acetate, $0.015 \%$ enzyme preparation Alphamalt V and $0.006 \%$ ascorbic acid 


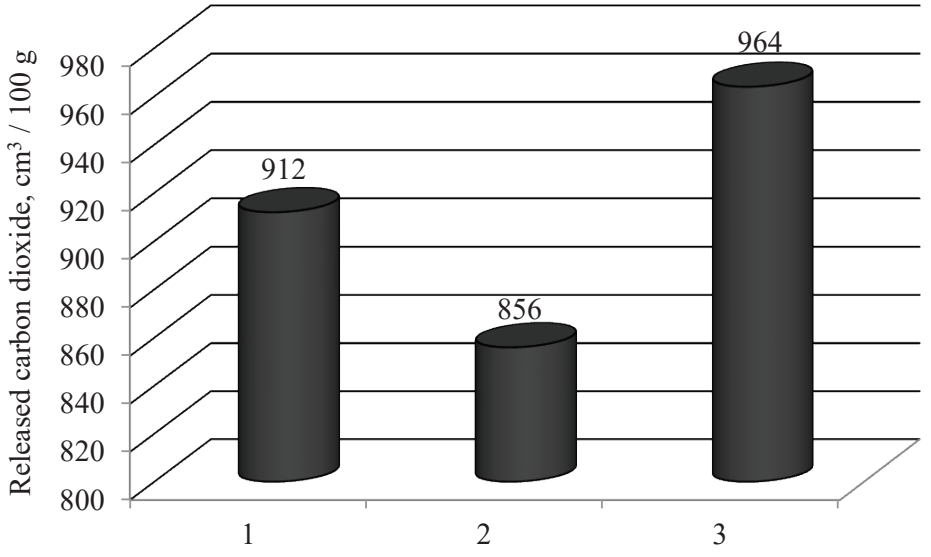

Fig. 2. The effect of food additives on the release of carbon dioxide: 1 - control (without additives); $2-0.3 \%$ calcium acetate; $3-0.3 \%$ calcium acetate, $0.015 \%$ enzyme preparation Alphamalt V and $0.006 \%$ ascorbic acid

Structural and mechanical properties of the dough according to the pharynograph, $n=3, p \leq 0.95$

\begin{tabular}{|l|c|c|c|}
\hline \multicolumn{1}{|c|}{ Indicators } & Control & $\begin{array}{c}0.3 \% \\
\text { calcium } \\
\text { acetate }\end{array}$ & $\begin{array}{c}0.3 \% \text { calcium acetate, } \\
0.015 \% \text { enzyme prepa- } \\
\text { ration Alphamalt V and } \\
0.006 \% \text { ascorbic acid }\end{array}$ \\
\hline Consistency, units instrument & 500 & 500 & 500 \\
\hline Water retention ability, cm ${ }^{3} / 100$ g & 57.5 & 57.4 & 57.8 \\
\hline Formation duration, min & 4 & 5 & 165 \\
\hline Elasticity, units instrument & 160 & 130 & 3.75 \\
\hline Stability, min & 3.5 & 3.0 & 70 \\
\hline $\begin{array}{l}\text { Vacuum during the batch, 15 min. } \\
\text { units instrument }\end{array}$ & 70 & 100 & \\
\hline
\end{tabular}

The elongation of the dough is largely dependent on its elasticity. Despite this, it is possible to assume the best gas-retaining ability of the dough samples. To confirm this, let's changes in the volume of dough in a measuring cylinder by $500 \mathrm{~cm}^{3}$ at a temperature of $30{ }^{\circ} \mathrm{C}$ for $4 \mathrm{~h}$ of fermentation. It is established (Fig. 3) that when the enzyme preparation Alphamalt $\mathrm{V}$ and ascorbic acid are added, the specific volume of the dough increases by $28 \%$ compared to the dough with calcium acetate. This is due to the strengthening of the protein molecule as a result of the formation of disulfide bridges by the oxidation of adjacent sulfhydryl groups by ascorbic acid.

The effect of calcium acetate and food additives on the spreading of dough balls during fermentation was further investigated. The research results are shown in Fig. 4. It is found that in samples with $0.3 \%$ calcium acetate, $0.015 \%$ enzyme prepara-

Table 2 tion Alphamalt $\mathrm{V}$ and $0.006 \%$ ascorbic acid, the spreading slightly increased compared to the control. But it is much less than in calcium acetate products without food additives (spreading decreased by $15.2 \%$ ). This is the basis for improving the dimensional stability of calcium acetate products.

The quality of bakery products, their specific volume, shape stability, structure and elasticity of the crumb largely depend on the structural and mechanical properties of the dough and biochemical processes.

The obtained regularities of the influence of food additives on the formation of structural and mechanical properties of the dough determine the formation of the quality of finished products (Table 3 ). According to the results of test laboratory baking, it is found that in the case of adding $0.015 \%$ of the enzyme preparation Alphamalt $\mathrm{V}$ and $0.006 \%$ ascorbic acid into the dough with calcium acetate, a significant improvement in the quality of the products is achieved. This is explained by the positive effect of food additives on microbiological processes and the improvement of the structural and mechanical properties of the dough.

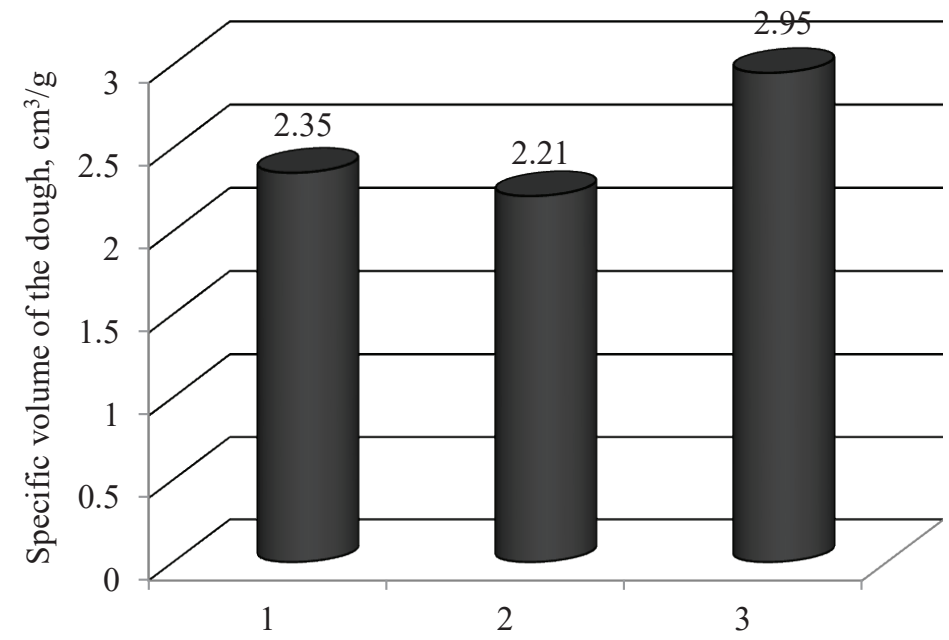

Fig. 3. The effect of food additives on the specific volume of the dough:

1 - control (without additives); 2 - $0.3 \%$ calcium acetate; $3-0.3 \%$ calcium acetate, $0.015 \%$ enzyme preparation Alphamalt V and $0.006 \%$ ascorbic acid 


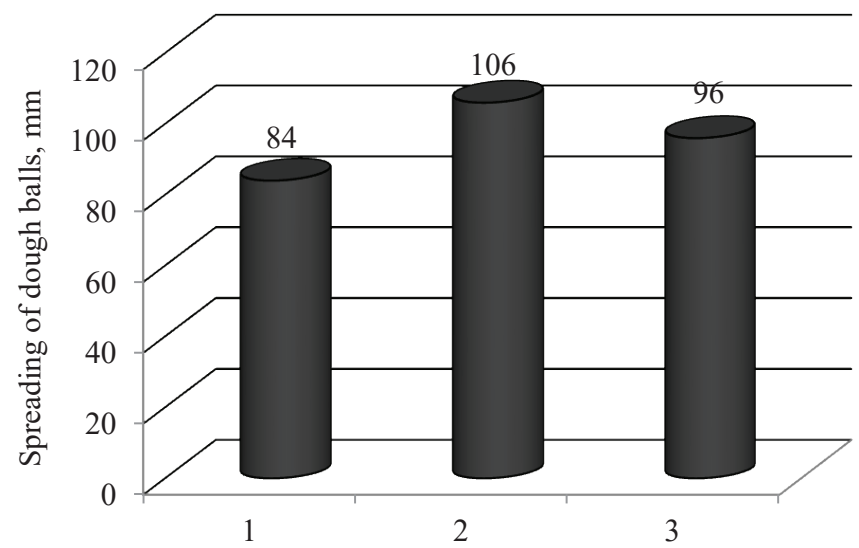

Fig. 4. The effect of food additives on the spreading of dough balls:

1 - control (without additives); $2-0.3 \%$ calcium acetate; $3-0.3 \%$ calcium acetate, $0.015 \%$ enzyme preparation Alphamalt $\mathrm{V}$ and $0.006 \%$ ascorbic acid

The performance of the process and the quality of wheat bread, $n=3, p \leq 0.95$

Table 3

\begin{tabular}{|c|c|c|c|}
\hline \multirow[b]{2}{*}{ Indicator } & \multirow[b]{2}{*}{ Control (without additives) } & \multicolumn{2}{|c|}{ Additives, $\%$ by weight of flour } \\
\hline & & $0.3 \%$ calcium acetate & $\begin{array}{l}0.3 \% \text { calcium acetate, } 0.015 \% \\
\text { enzyme preparation Alphamalt V } \\
\text { and } 0.006 \% \text { ascorbic acid }\end{array}$ \\
\hline \multicolumn{4}{|c|}{ Dough } \\
\hline \multicolumn{4}{|l|}{ Titratable acidity, degrees: } \\
\hline - initial & 2.1 & 2.1 & 2.1 \\
\hline- final & 3.2 & 2.9 & 3.2 \\
\hline $\mathrm{CO}_{2}$ emitted during fermentation and proofing, $\mathrm{cm}^{3} / 100 \mathrm{~g}$ & 648 & 571 & 694 \\
\hline Spreading of dough balls, \% & 84 & 102 & 88 \\
\hline Increase dough volume in 4 hours of fermentation, \% & 128 & 108 & 136 \\
\hline Proofing duration, min & 55 & 68 & 55 \\
\hline \multicolumn{4}{|c|}{ Finished products } \\
\hline Specific Volume, $\mathrm{cm}^{3} / \mathrm{g}$ & 3.59 & 3.28 & 3.60 \\
\hline Form Resistance, H/D & 0.41 & 0.36 & 0.44 \\
\hline Porosity, \% & 74 & 71 & 76 \\
\hline Penetration of the crumb, units instrument & 92 & 84 & 106 \\
\hline Surface condition & \multicolumn{3}{|c|}{ 5mooth without cracks and blasts } \\
\hline Crust color & Brown & Light brown & Brown \\
\hline Crumb condition & Elastic & Jammed & Elastic \\
\hline Porosity structure & $\begin{array}{l}\text { Small, uniform, developed, } \\
\text { thin-walled }\end{array}$ & $\begin{array}{l}\text { Medium, uniform, developed, } \\
\text { thin-walled }\end{array}$ & $\begin{array}{l}\text { Small, uniform, developed, } \\
\text { thin-walled }\end{array}$ \\
\hline Taste and aroma & \multicolumn{3}{|c|}{ Peculiar to this product, without undue smacks and smells } \\
\hline
\end{tabular}

The introduction of the enzyme preparation Alphamalt $\mathrm{V}$ and ascorbic acid increases the specific volume of bakery products from acetate by $10 \%$ compared with products from calcium acetate. Significantly improves their dimensional stability. So, in products made of calcium acetate, Alphamalt $\mathrm{V}$ enzyme preparation and ascorbic acid, shape stability improved by $15.4 \%$ compared to products with only calcium acetate. The porosity when using food additives exceeded the control and with calcium acetate by $2.6 \%$ and $5.2 \%$, respectively.

Organoleptic evaluation of product quality shows that with the use of calcium acetate together with the studied additives, significant improvement in product quality can be achieved.

\section{Conclusions}

Research results show that calcium acetate inhibits microbiological processes in the dough, causing deterioration in the intensity of alcoholic and lactic acid fermentation. Along with this, its structural and mechanical properties are deteriorating.

It is shown that in order to improve the quality of calcium acetate products, it is advisable to use the enzyme preparation Alphamalt $\mathrm{V}$ and ascorbic acid. At a dosage of the enzyme preparation Alphamalt V $-0.015 \%$ by weight of flour, ascorbic acid - $0.006 \%$, the quality of semi-finished products and finished products significantly improves. It is also shown that the use of food additives 
in dough with calcium acetate improves the gas removal capacity by $15 \ldots 20 \%$, the lifting force of the yeast, its elastic properties, the gas removal capacity increases by $30 \ldots 40 \%$, and the casting of dough pieces decreases by $15 \ldots 20 \%$. This leads to an increase in the specific volume of bakery products by $10 \ldots 13 \%$ compared with products with only calcium acetate.

\section{References}

1. Kolomnikova, Ia. (2009). Tekhnologicheskie priemy po preduprezhdeniiu zabolevanii khlebobulochnykh izdelii. Khleboprodukty, 3, 51-53.

2. Drobot, V. I. (2019). Dovidnyk z tekhnolohii khlibopekarskoho vyrobnytstva. Kyiv: ProfKnyha, 580.

3. Yaroshevych, T. S. (2011). Suchasni metody diahnostuvannia kartoplianoi khvoroby khliba ta zasoby zapobihannia yii rozpovsiudzhenniu. Visnyk Khmelnytskoho natsionalnoho universytetu (tekhnichni nauky), 2, 124-127.

4. Eveleva, V. V., Cherpalova, T. M. et. al. (2010). Kompleksnye laktatsoderzhaschie pischevye dobavki dlia preduprezhdeniia kartofelnoi bolezni khleba. Pischevye ingredienty: syre i dobavki, 2, 68-69.

5. Osimani, A., Zannini, E., Aquilanti, L., Mannazzu, I., Comitini, F., Clementi, F. (2009). Lactic acid bacteria and yeasts from wheat sourdoughs of the Marche region. Italian Journal of Food Science, 21 (3), 269-286.

6. Leipurin. Available at: https://www.leipurin.com/ua/contact-us

7. Auerman, L. Ia. (2009). Tekhnologiia khlebopekarnogo proizvodstva. Saint Petersburg: Professiia, 416

8. Polandova, R. D. et. al. (2007). Sostoianie i perspektivy ispolzovaniia propionovokislykh bakterii v proizvodstve pshenichnogo khleba. Khranenie i pererabotka selkhozsyria, 5, 55-57.
9. Zhang, C., Brandt, M. J., Schwab, C., Gänzle, M. G. (2010). Propionic acid production by cofermentation of Lactobacillus buchneri and Lactobacillus diolivorans in sourdough. Food Microbiology, 27 (3), 390-395. doi: http://doi.org/10.1016/ j.fm.2009.11.019

10. Bilyk, O. A. (2006). Udoskonalennia tekhnolohii khlibobulochnykh vyrobiv z boroshna zi znyzhenymy khlibopekarskymy vlastyvostiamy. Kyiv, 20.

11. Lebedenko, T. Ye., Pshenyshniuk, H. F., Sokolova, N. Yu. (2014). Tekhnolohiia khlibopekarskoho vyrobnytstva. Praktykum. Odessa: Osvita Ukrainy, 392.

12. Drobot, V. I. (Ed.) (2015). Tekhnokhimichnyi kontrol syrovyny ta khlibobulochnykh i makaronnykh vyrobiv. Kyiv: NUKhT, 948.

Bilyk Olena, PhD, Associate Professor, Department of Bakery and Confectionary Goods Technology, National University of Food Technologies, Kyiv, Ukraine, e-mail: bilyklena@gmail.com, ORCID: http://orcid.org/0000-0003-3606-1254

Kochubei-Lytoynenko Oksana, PhD, Associate Professor, Department of Milk and Dairy Technology, National University of Food Technologies, Kyiv, Ukraine, e-mail: okolit@email.ua, ORCID: http:// orcid.org/0000-0003-0712-448X

Bondarenko Yulia, PhD, Associate Professor, Department of Bakery and Confectionary Goods Technology, National University of Food Technologies, Kyiv, Ukraine, e-mail: bjuly@ukr.net, ORCID: http:// orcid.org/0000-0002-3781-5604

Chernyushok Olha, PhD, Department of Technology of Meat and Meat Products, National University of Food Technologies, Kyiv, Ukraine, e-mail: chernyushokolga@ukr.net, ORCID: https:// orcid.org/0000-0001-7384-3170 